\title{
自閉スペクトラム症における視線による注意シフト と自己関連づけ効果の関係性
}

\author{
$\bigcirc^{\text {趙朔 }}{ }^{1} \cdot$ 魚野翔太 ${ }^{2} \cdot$ 義村さや香 ${ }^{2} \cdot$ 十一元三 ${ }^{1, \#}$ \\ ( ${ }^{1}$ 京都大学大学院医学研究科人間健康科学系専攻・ ${ }^{2}$ 京都大学医学研究科発達障害支援医学講座 $)$ \\ キーワード：自閉スペクトラム症, 視線注意, 自己関連付け効果
}

\begin{abstract}
Influence of self-relevant processing on the gaze cueing effect in autism spectrum disorder
Shuo $\mathrm{ZHAO}^{1}$, Shota $\mathrm{UONO}^{2}$, Sayaka YOSHIMURA ${ }^{2}$ and Motomi TOICHI ${ }^{1, \#}$

( ${ }^{1}$ Faculty of Human Health Science, Graduate School of Medicine, Kyoto University., ${ }^{2}$ Department of Neurodevelopmental Psychiatry, Habilitation and Rehabilitation, Graduate School of Medicine, Kyoto University)

Key Words: Autism spectrum disorder, Gaze cueing effect, Self-referential effect
\end{abstract}

\section{目 的}

自閉スペクトラム症 (ASD) は対人的相互反応の障害を主症 状とし、代表的なものに他者と同じ事物に視線を向けて注意 を配分する共同注意の障害がある。

しかしながら、他者の視線による注意シフトについて調べ た研究ではASD で明確な障害があるということは示されてい ない。本研究は、現実場面での共同注意の障害と実験場面で 視線による注意シフトが生じることのかい離の原因について、 自己関連付け効果という現象を取り上げて検討する。

複雑な日常環境では自己と関連性の高い情報を他の情報と 区別して処理することが重要である。先行研究では、定型発 達者（TD）が他者の視線などの方向手掛り刺激が自己と関連 付けられることで視線による注意シフトのパターンが影響さ れることが報告されている。ASD では自己処理の一部に障害 がみられるため、定型発達者と自己関連付けが視線による注 意シフトに与える影響が定型発達者とは異なる可能性がある と考えられる。

本研究では、群間で知能指数、年齢、性別をマッチングし た上で、視線手掛り刺激の自己関連性の違いに応じた注意シ フトパターンの変化が群間で異なるか検討し、さらに症状の 重症度との関係について検討した。

\section{方 法}

参加者 $\mathrm{ASD}$ 者 21 名 (平均年齢 24.1 歳、男性 12 名、 $\mathrm{CARS}^{1 \text { ) }}$ 平均得点 24. 4) および $\mathrm{TD}$ 者 20 名 (平均年齢 23.3 歳、男性 14 名)が実験に参加した。

手続きと解析 はじめにトレーニング課題を行い、「自己」も しくは「他人」という単語と中性表情の顔刺激（男性もしく は女性）を同時に呈示して、特定の組み合わせの連合を強化 した（例えば、自己－男性顔、他人 - 女性）。

次に、「自己」もしくは「他人」と連合した顔の左右いずれ かを向いた視線を手掛り刺激、人の声もしくは純音をターゲ ット刺激として、手がかり注意課題を行った。この課題では、 呈示された長さ $200 \mathrm{~ms}$ での手掛り刺激に後続して左右どちら かの耳に呈示される長さ $150 \mathrm{~ms}$ でのターゲットに対する反応 時間を計測した。手がかり刺激とターゲットの出現位置が不 一致の場合と一致の場合の反応時間の差分を算出し、注意シ フトの大きさの指標とした。2 群 $(\mathrm{ASD} / \mathrm{TD}) \times 2$ 手掛り刺激 (自 己/他者) $\times 2$ ターゲット(人の声/純音) の反復測定分散分析を 行った。最後に、自己関連付け効果によって ASD 症状の重症 度への影響を評価するために、「自己」と連合した視線による 注意シフトに影響する程度と CARS 得点について相関係数を 算出した。

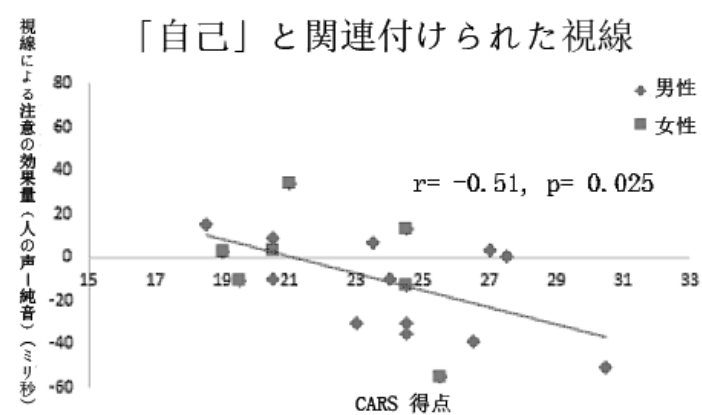

図 1.「自己」と連合した視線による注意の効果量と CARS 得点の相関

結 果

トレーニング課題では両群ともに「他人」より「自己」と 連合した条件により速く反応した $(\mathrm{F}[1,37]=49.0, p<$ 0.001)。注意課題では両群ともに手掛かりとターゲットの種 類に関わらず有意な注意シフトが生じることが示された。TD 群では、「他人」と連合した手掛りと比べ、「自己」と連合し た手掛りを用いたときにターゲットが人の声の時の手掛り効 果が大きいことが示された $(p=0.038)$ 。一方、ASD 群では「他 人」と比べて「自己」と連合した手掛りを用いたときに純音 ターゲットに対する手掛かり効果が大きいことが見られた $(p$ $=0.035)$ 。人の声と純音がターゲットの時の手掛り効果の差 は CARS 得点と負の相関 $(r=-0.51, p=0.025)$ を示した。

考 察

両群で視線による注意シフトが生じることが示された。ま た、「自己」と連合した手掛かり刺激において、TD 群では人 の声がターゲット刺激であるときに強い注意シフトが生じる が、ASD 群では純音がターゲット刺激であるときに強い注意 シフトが生じることが見られた。この結果から、ASD 者は TD 者と同じように視線手がかりが「自己」と連合したことに応 じて注意シフトが強くなれるが、そのパターンが非定型だと 考える。さらに、ASD 者ではこの強さと ASD 症状の重症度と 負の相関をしめすことから、ASD では自己関連付け効果によ って ASD 症状の重症度に影響できることが示唆された。

\section{引用文献}

1) Schopler, E., Reichler, R. J. , \& Renner, B. R. (1986). Childhood Autism Rating Scale (CARS) for diagnostic screening and classification of autism. New York, NY: Irvington. 